\title{
Putting the Dutch Child Labour Due Diligence Act into Perspective
}

\author{
An Assessment of the CLDD Act's Legal and Policy Relevance in the Netherlands and Beyond
}

\author{
Liesbeth Enneking*
}

\begin{abstract}
In May 2019, the Dutch senate adopted a private member's bill introducing a due diligence obligation for companies bringing goods or services onto the Dutch market with respect to the use of child labour in their supply chains. The aim of this article is to place this Child Labour Due Diligence (CLDD) Act in the national and international legal context and to discuss its relevance for the broader debate on international responsible business conduct (IRBC) in global value chains. The article shows that the CLDD Act introduces a due diligence obligation in this context that is new to Dutch law, as is the public law supervisor that is to be tasked with its enforcement. However, it does nothing to broaden the possibilities for access to remedies for victims of child labour beyond those already in existence. The article also shows that when compared with 2017 the French Duty of Vigilance Law, which is the only other mandatory due diligence law to have been adopted so far, the CLDD Act stands out in several respects. It is overshadowed, however, by the European parliament's recent adoption of an ambitious outline for a future EU due diligence directive. Nonetheless, in view of the fact that it remains unclear for now whether the future EU directive on this topic will display the same level of ambition as the current proposal, the CLDD Act will remain relevant from an international perspective also for some time to come.
\end{abstract}

Keywords: Mandatory Due Diligence, Responsible Business Conduct, Child Labour Due Diligence Act

\section{Introduction}

In May 2019, the Dutch senate adopted a private member's bill seeking to introduce a due diligence obligation for companies bringing goods or services onto the Dutch market with respect to the use of child labour in their supply chains. ${ }^{1}$ The bill had been adopted by the

* Liesbeth Enneking is Professor of Legal Aspects of International Corporate Social Responsibility at Erasmus School of Law, Erasmus University Rotterdam.

1. Wet van 24 oktober 2019 houdende de invoering van een zorgplicht ter voorkoming van de levering van goederen en diensten die met behulp van kinderarbeid tot stand zijn gekomen (Wet zorgplicht kinderarbeid), Stb. 2019, $401 \quad$ (13 November 2019), zoek.officielebekendmakingen.nl/stb-2019-401.html.
Dutch house of representatives in early 2017, but faced strong opposition in the Dutch senate for various reasons. ${ }^{2}$ Nevertheless, it was passed by a small majority of senators and was expected to enter into force in 2022. However, recent developments have cast doubt on whether and when this Wet Zorgplicht Kinderarbeid (referred to herein as the Child Labour Due Diligence Act or CLDD Act) will actually take effect (see para. 2.2). Yet its adoption arguably constitutes a salient point in the sociopolitical debate on international responsible business conduct (IRBC) in the Netherlands and internationally and is interesting from both a legal and a policy perspective.

Since 2014, the Dutch policy on IRBC in global value chains - which was strongly influenced by the $2011 \mathrm{UN}$ Guiding Principles on Business and Human Rights (UNGPs) $^{3}$ and the 2011 revision of the OECD Guidelines for Multinational Enterprises ${ }^{4}-$ has mainly been focused on the conclusion of multistakeholder agreements with certain sectors of the Dutch industry. ${ }^{5}$ These so-called IRBC agreements resulted from a 2014 sector risk analysis, in which thirteen sectors of the Dutch industry were identified as involving relatively high risks of adverse impacts on human rights and the environment. ${ }^{6}$ To date, eleven IRBC agreements have

2. See, for an overview of the debate and relevant documents: eerstekamer.nl/wetsvoorstel/34506_initiatiefvoorstel_kuiken.

3. 'Guiding Principles on Business and Human Rights: Implementing the United Nations "Protect, Respect and Remedy" Framework, UN Doc. A/HRC/17/31 (21 March 2011), ohchr.org/documents/publications/ guidingprinciplesbusinesshr_en.pdf.

4. OECD, OECD Guidelines for Multinational Enterprises (OECD Publishing 2011).

5. See, for an overview and critical review of this policy, Ministry of Foreign Affairs of the Netherlands, Policy and Operations Evaluation Department (IOB), Mind the Governance Gap, Map the Chain - Evaluation of the Dutch Government's Policy on International Responsible Business Conduct (2012-2018) (September 2019), rijksoverheid.nl/ documenten/rapporten/2019/11/22/bijlage-kamerbrief-inzake-iobevaluatie-imvo-beleid.

6. KPMG, 'MVO Sector Risico Analyse - Aandachtspunten voor dialoog', report for the Dutch Minister of Foreign Trade and Development Cooperation and the Dutch Minister of Economic Affairs (September 2014), rijksoverheid.nl/documenten/rapporten/2014/09/01/mvo-sector-risicoanalyse. The report identified the construction, chemicals, retail, energy, financial services, wholesale, wood and paper, agriculture and horticulture, oil and gas, garments and textile, food, electronics and metal sectors as being of high risk in this context. 
been concluded, and one more is being developed. ${ }^{7}$ There are differences in scope and form between the various covenants but the one thing they all have in common is that the adhering companies have committed themselves to implementing and carrying out due diligence procedures to identify and deal with IRBC-related risks in their value chains.

One of the consequences of the Dutch government's focus in its IRBC policy on concluding sector agreements - a regulatory instrument that is, in essence, consensus driven - has been that it has effectively held off concrete debate on the introduction of more binding measures in this context. In this sense, developments in the Netherlands have, over the past few years, moved in a different direction from those in countries like the UK, France and Switzerland, where specific legislation on certain key issues in the IRBC context was realised. Importantly, however, the Dutch government's 2017 coalition agreement stipulated not only that the policy of IRBC agreements would be continued, but also that in two years the possibility of more binding measures was to be considered. ${ }^{8}$ This commitment more or less accidentally - or so it seems - coincided with the adoption by the Dutch lower house of parliament of the bill for what was to become the CLDD Act following its adoption by the senate in 2019 .

The aim of this article is to place the CLDD Act in a national and international legal context and to assess its relevance for the broader debate on the legal aspects of IRBC in global value chains. The article begins with an overview of the Act's key provisions and discusses the main points of criticism raised over the course of the parliamentary debate as well as its current status quo (para. 2). This is followed by a discussion of its place within the Dutch legal framework, with a focus on IRBC-related duties of care in the fields of Dutch company law and Dutch tort law (para. 3). Subsequently, the Act will be placed in the international context by examining similarities and differences with respect to similar legislative initiatives in other European countries and at the EU level, followed by a discussion of its international relevance (para. 4). The article concludes with a note on the CLDD Act's legal and policy relevance in the Netherlands and beyond (para. 5).

7. See, for an overview, imvoconvenanten.nl/en. The existing agreements relate to garments and textile, banking, gold, natural stone, food products, insurance, pension funds, metals, floriculture, sustainable forestry and wind energy. The agreement currently under development relates to the agricultural sector.

8. Regeerakkoord 'Vertrouwen in de toekomst' (10 October 2017), kabinetsformatie2017.nl/documenten/publicaties/2017/10/10/ regeerakkoord-vertrouwen-in-de-toekomst, p. 49.

\section{The Dutch Child Labour Due Diligence Act: An Overview}

\subsection{Key Provisions 9}

The CLDD Act was introduced in June 2016 in the Dutch house of representatives as a private member's bill by an MP from the Dutch Labour Party. Although the Act has undergone various changes over the course of the legislative process, its essence has remained the same: to introduce an obligation for companies bringing goods or services onto the Dutch market to conduct due diligence (gepaste zorgvuldigheid) with a view to preventing child labour from being used in the production of those goods and services. In the preamble, this aim is connected to that of consumer protection:

a statutory basis for the requirement that companies selling goods and services on the Dutch market take all reasonable measures to prevent the use of child labour in the production of those goods and services is desirable in order to ensure that consumers can purchase those goods and services in good conscience. $^{10}$

The CLDD Act requires every company that supplies goods or services to Dutch end users, ${ }^{11}$ regardless of whether the company is registered in the Netherlands or abroad, to issue a declaration that it conducts due diligence with a view to preventing child labour from being used in the production of those goods and services. ${ }^{12}$ The declaration needs to be submitted to the public law supervisor charged with overseeing compliance with the proposed act, which will publish the declarations in an online registry on its website. ${ }^{13}$ The Act contains no further requirements as to the timing of such declarations or as to their form and contents but does provide that further requirements may be set through secondary legislation. ${ }^{14}$ It has been noted during the parliamentary discussions that if an implementation regulation setting out further requirements stays out, under the Act's current wording a one-sentence declaration would, in fact, suffice in order for the companies involved to dispose of this particular obligation.

Inherent in the obligation to issue due diligence declarations with respect to goods and services that are to be supplied to Dutch end users is the obligation to actually

9. Parts of this section have also been used in: L. Enneking, 'The Netherlands Country Report', in Study on Due Diligence Requirements Through the Supply Chain - Part III: Country Reports (20 February 2020), op.europa.eu/en/publication-detail/-/publication/ 0268dfcf-4c85-11ea-b8b7-01aa75ed71a1/language-en, pp. 170-96.

10. Preamble CLDD Act (translation by the author).

11. According to the Act's preamble, this means 'the natural or legal persons that use or use up the goods or make use of the services'.

12. Art. 4(1) CLDD Act. Child labour is defined in the Act along the lines of ILO Conventions C138 (the Minimum Age Convention) and C182 (the Worst Forms of Child Labour Convention). See Art. 2 CLDD Act.

13. Art. 4(2) and 4(5) CLDD Act.

14. Art. 4(3) CLDD Act. See, generally, on the Dutch legislative process: overheid.nl/english/about-the-dutch-government/what-governmentdoes/how-an-act-becomes-law\#EN005 
conduct such due diligence. According to the CLDD Act, a company conducts due diligence by investigating whether there is a reasonable presumption that the goods and services to be supplied have been produced with the help of child labour and by drawing up and carrying out an action plan if the investigation reveals that such a presumption exists. ${ }^{15}$ The investigation needs to be based on sources that can reasonably be known to the company and that are accessible to it. ${ }^{16}$ The Act does not provide any further guidance with respect to the due diligence requirement. It does, however, provide that more detailed requirements with respect to both the investigation and the action plan are to be set through secondary legislation, taking account of the existing ILO-IOE Child Labour Guidance Tool for Business. ${ }^{17}$

Companies that buy goods or use services from a supplier that has submitted a declaration with respect to those goods or services along the lines set out in the Act are assumed to have conducted due diligence with respect to those goods or services. Companies that buy goods or services exclusively from suppliers that have submitted declarations with respect to those goods or services along the lines set out in the bill are also assumed to have conducted due diligence and are, moreover, not required to issue a declaration themselves. ${ }^{18}$ Furthermore, the Act provides that the Dutch minister for foreign trade and development cooperation can approve a joint action plan that has been concluded between one or more civil society organisations, trade unions and/or employers' organisations and that aims to make the participating companies conduct due diligence in order to prevent the use of child labour in the production of goods and services. Any company that conducts its business in accordance with such a joint action plan - which refers to the aforementioned IRBC agreements - is assumed to conduct due diligence along the lines set out in the Act. ${ }^{19}$

Not all types of companies are subject to (the obligations set out in) the CLDD Act. First of all, it is evident from the description of its scope that companies that do not supply goods or services to Dutch end users are not bound by it. Second, it provides that companies that are merely involved in transporting the goods in question are exempted from compliance with the act. ${ }^{20}$ In addition, it leaves open the possibility that certain other categories of companies can also be exempted from compliance with the proposed act through secondary legislation. ${ }^{21}$ These other categories of companies may include, for instance, small companies and/or companies from low-risk sectors. Further exemptions follow from its aforementioned provisions relating to companies that buy goods or use services from suppliers that

\footnotetext{
15. Art. 5(1) CLDD Act.

16. Art. 5(2) CLDD Act.

17. Art. 5(3) CLDD Act.

18. Art. 5(1) CLDD Act.

19. Art. 5(4) CLDD Act.

20. Art. 4(4) CLDD Act.

21. Art. 6 CLDD Act.
}

themselves comply with the CLDD Act and to those conducting their business in accordance with government-approved joint action plans.

A public law supervisor, which is to be appointed by secondary legislation, ${ }^{22}$ will monitor and enforce compliance with the provisions set out in the CLDD Act. The Act provides that any natural or legal person whose interests have been affected by the failure of a company to comply with the provisions set out in the Act can file a complaint with the supervisor, but only if and insofar as there are specific indications of non-compliance by a specific company. ${ }^{23}$ The supervisor will respond only to complaints that have first been filed with the company, but that have not been dealt with by the company within six months or have not been dealt with satisfactorily. ${ }^{24}$

In response to a complaint, the supervisor can issue a binding order to a company that fails to comply with the provisions set out in the Act and can also set a deadline for compliance with that order. ${ }^{25}$ If the company does not comply with the supervisor's order, the supervisor can impose administrative fines of: 1 ) up to $€ 4,100$ for non-compliance with the duty to file a declaration (or up to $€ 8,200$ if the aforementioned amount is not considered appropriate); and 2) up to $€ 820,000$ for noncompliance with the duty to conduct due diligence along the lines set out in the Act (or up to $10 \%$ of the company's annual turnover if the aforementioned amount is not considered appropriate). ${ }^{26}$

Additionally, criminal sanctions can be imposed on (officers of) companies that are repeat offenders. If, within five years of the imposition of an administrative fine, a similar transgression is committed by the company by order or under supervision of the same (de facto) director, this is considered a criminal offence. If this second transgression was committed without intent, it is considered a misdemeanour, punishable by a maximum of six months' detention and a $€ 21,750$ fine. If the second transgression was committed with intent, it is considered a crime, punishable by a maximum of two years' imprisonment and a $€ 21,750$ fine. $^{27}$

\subsection{Main Points of Criticism and Status Quo}

Although it was adopted in May 2019 by a majority vote in the Dutch senate, the CLDD Act has not remained undisputed. The arguments against adoption of the Act that have been raised can roughly be categorised into arguments pertaining to legal uncertainty; insufficiently founded choices as to the Act's scope and aims; and non-feasibility of its monitoring and enforcement mechanisms. ${ }^{28}$ One of the main points of contention with respect to legal uncertainty has been the strong

\footnotetext{
Art. 1(d) CLDD Act.

Art. 3(2) and 3(3) CLDD Act.

Art. 3(4) CLDD Act.

Art. 7(4) CLDD Act.

26. Art. 7(1)-7(3) CLDD Act. Note that the amounts mentioned are subject to change.

27. Art. 9 CLDD Act. Note that the amounts mentioned are subject to change.

28. See, in particular, the parliamentary reports of the general debates in the senate relating to the Act on 19 December 2017 and on
} 
reliance in the Act on secondary legislation that is yet to be drafted for issues that are fundamental for its scope and consequences. These include a more detailed description of the requirements for the due diligence obligation that forms its core, the possible exemption of certain categories of companies from the Act's obligations, and - perhaps even most crucially in practice since there do not seem to be any obvious or willing candidates - which supervisory body is to enforce compliance with the Act.

A major point of debate with respect to the Act's scope and aims has been its single-issue focus on preventing child labour rather than the protection of human rights and the environment more broadly, as well as its stated aim of consumer protection rather than the protection of the actual victims of child labour. These features set it apart from IRBC-related legislative initiatives in various other EU member states, as will be discussed further below (see para. 4). In addition, and connected to this, the Act has been criticised for not containing any provisions relating to access to remedy for the actual victims of child labour - other than the fact that they can file a complaint with the supervisor, which may then take action. In this sense, the Act does not add any new avenues for recourse to those that already exist on the basis of, for example, Dutch tort law (see para. 3).

Points of criticism raised with respect to the Act's monitoring and enforcement mechanisms have included the ongoing uncertainty surrounding the public law supervisor, as it still remains unclear whether supervision is to be undertaken by one or a combination of existing supervisory bodies in the Netherlands (examples mentioned include the Authority for Consumers \& Markets and the Dutch National Contact Point) or whether it would require the establishment of a new, dedicated supervisor. Another point of criticism has been that despite the Act's international scope in regard to companies covered - it applies to all companies, both Dutch and foreign, that deliver goods or services to Dutch end users - in effect the actual monitoring and enforcement of compliance with its provisions will likely be predominantly targeted at Dutch companies owing to extraterritoriality issues. Questions have also been raised with respect to the fact that the public law supervisor, according to the current version of the bill, will only take monitoring and/or enforcement action on receiving a complaint by a third party, rather than initiating inquiries independently. Furthermore, the Dutch public prosecutor's role in enforcing the Act against repeat offenders is expected to be limited in practice owing to a lack of the necessary capacity and funds, in combination with the low prioritisation of IRBC-related cases (see also para. 2.4).

Despite these objections, the bill was passed in May 2019 as a small majority of senators from different political parties, including, crucially, the minister of foreign trade and development cooperation's own liberal-

23 April 2019, eerstekamer.nl/wetsvoorstel/34506_initiatiefvoorstel_ kuiken democratic party (D66), voted in favour of it. In the definitive version of the CLDD Act, which was published in the Dutch Bulletin of Acts and Decrees in November 2019, it was stipulated that the Act was to enter into force at a later date so as to be determined by royal decree, but no sooner than 1 January 2020. In the debate before the senate, it had already been mentioned that because many crucial details of the Act still needed to be worked out by the government through orders in council, it was not expected to enter into force before 2022. ${ }^{29}$

However, recent developments have cast doubt on whether the CLDD Act will come into effect at all. In October 2020, following an extensive and rather critical evaluation of the results of its IRBC policy so far ${ }^{30}$ the Dutch government issued a revised IRBC policy pursuing a new mix of policy instruments that will also be centred on a broad due diligence obligation. ${ }^{31}$ At the same time, it expressed a strong preference for an EUwide legislative approach on this issue and indicated that it will therefore await the developments to this effect that are currently taking place at the EU level. In line with this, the government also indicated that it will wait and see whether such an EU-wide obligation will in fact be realised before implementing the CLDD Act and that it is prepared to abandon implementation altogether if this is to be so. ${ }^{32}$ It plans to take stock of the relevant developments at the EU level in the summer of 2021 (at the earliest) and is, in the meantime, working out remaining issues pertaining to the CLDD Act. ${ }^{33}$

\section{Relevance for Dutch Law and Policy}

\subsection{Introduction}

The due diligence obligation that the CLDD Act introduces into Dutch law with respect to IRBC (in particular, the use of child labour) in global value chains is new to Dutch law. Although resolutions of international organisations can, in principle, take direct effect in the Dutch legal order, the UN Guiding Principles and the OECD Guidelines are non-binding, which means that they do not in themselves create a legal obligation for business enterprises to conduct due diligence or to com-

29. See the parliamentary report of the general debate in the senate relating to the Act on 23 April 2019, eerstekamer.nl/wetsvoorstel/ 34506_initiatiefvoorstel_kuiken.

30. See above $\mathrm{n} 3$.

31. Ministerie van Buitenlandse Zaken, 'Van voorlichten tot verplichten Een nieuwe impuls voor internationaal maatschappelijk verantwoord ondernemerschap' (16 October 2020), rijksoverheid.nl/documenten/ beleidsnotas/2020/10/16/van-voorlichten-tot-verplichten-een-nieuweimpuls-voor-internationaal-maatschappelijk-verantwoordondernemerschap.

32. Brief van de Minister voor Buitenlandse Handel en Ontwikkelingssamenwerking, 16 October 2020, Kamerstukken II 2020-21, 26485, nr. 337.

33. Brief van de Minister voor Buitenlandse Handel en Ontwikkelingssamenwerking, 11 February 2021, Kamerstukken II 2020-21, 26485, 364. 
ply with any of the other behavioural norms for corporate actors set out in them. Similarly, they do not create any obligations for states to enact due diligence legislation for companies within their jurisdiction. In that sense, the CLDD Act represents a significant development in Dutch law that also holds international relevance, especially given the fact that the obligation applies to Dutch and foreign companies alike, if and when they supply goods or services to Dutch end users. Another novel aspect of the CLDD Act pertains to the enforcement of the obligations set out in it by a public law supervisor.

Apart from these incontrovertibly novel elements, the question may be raised as to what the CLDD Act adds to existing norms for corporate actors in respect to IRBC in global value chains, in particular, duties of care owed by companies to third-party stakeholders in the IRBC context on the basis of Dutch company law and/or Dutch tort law. The concept of due diligence is the core concept of the second pillar of the UNGPs on the corporate responsibility to respect human rights, describing the steps a company is expected to take to become aware of, prevent and address adverse human rights impacts. There appears to be some ambiguity as to the exact meaning of the due diligence concept in the IRBC context, as it may be understood both as a procedural practice to assess and manage business risks and as a standard of conduct to take reasonable precaution to prevent, or to respond to, harm to stakeholders. In this latter sense, it actually closely resembles the written or unwritten duties of care in fields such as tort law and company law (and, albeit to a lesser extent, criminal law) that require corporate actors to take due care in preventing their activities from having an adverse impact on the interests of others. ${ }^{34}$

\subsection{Relevant Aspects of Dutch Company Law ${ }^{35}$}

Dutch company law applies in principle to all Dutch companies (i.e. all companies that are incorporated under Dutch law), regardless of where they carry out their operations. ${ }^{36}$ It does not currently feature any specific duties of care for Dutch companies or their directors in relation to third parties (host country workers, neighbours, communities) who might be negatively impacted by human rights violations or environmental degradation caused by the activities of business enterprises in their global value chains. It also does not contain any general obligations for Dutch companies to implement the key elements of the responsibility to

34. Cf, for instance, J. Bonnitcha and R. McCorquodale, 'The Concept of "Due Diligence" in the UN Guiding Principles on Business and Human Rights', 28 European Journal of International Law 899 (2017).

35. This section is largely based on: L. Enneking, F. Kristen, K. Pijl, T. Waterbolk, J. Emaus, M. Hiel, I. Giesen \& A. Schaap, Zorgplichten van Nederlandse ondernemingen inzake internationaal maatschappelijk verantwoord ondernemen (2016) 102-40. See also L. Enneking and R. Heesakkers, 'Vennootschappelijk belang en (internationaal) maatschappelijk verantwoord ondernemen', in B. Kemp, H. Koster \& C. Schwarz (eds.), De betekenis en functies van het vennootschappelijk belang (2019).

36. Arts. 10:117 and 10:118 Dutch Civil Code. respect as set out in the OECD Guidelines or the UNGPs, like human rights and environmental due diligence procedures. Nonetheless, there are some provisions and there is some case law in the field of Dutch company law that may provide starting points for the development of more concrete duties of care in relation to IRBC in global value chains.

A first starting point in Dutch company law that may over time lead to the development of IRBC-related duties of care is the requirement that directors (and supervisory directors) in the execution of their tasks are to focus on the interest of the business enterprise associated with the corporation. ${ }^{37}$ In the Netherlands, the notion of the corporate interest is interpreted broadly, in that it is considered to refer to the long-term interest of the business enterprise and comprises not only shareholder interests but also the interests of other stakeholders. ${ }^{38}$ According to the Dutch corporate governance code ${ }^{39}$ a company's stakeholders are those groups and individuals that have a direct impact on or that are directly impacted by the company's pursuit of its goals, including employees, shareholders and other capital providers, suppliers, customers and other interested parties. ${ }^{40}$ In executing their tasks (supervisory) directors are required to exercise due care with respect to the interests of all those who are directly involved in or linked to the corporation and the business enterprise that is associated with it. This means that they may need to refrain from doing things that would unnecessarily or unduly harm those interests. ${ }^{41}$

However, despite its broad interpretation and the duties of care that (supervisory) directors may have with respect to the interests of certain stakeholders, the point of departure in Dutch company law remains that the corporate interest comes first, unless the law or the company's articles of incorporation provide otherwise. ${ }^{42}$ Furthermore, there is no support in Dutch statutory or case law for an interpretation of the corporate interest and/or directors' duties that is as broad as to encompass

37. Arts. 2:129(5) / 2:239(5) and 2:140(2) / 2:250(2) Dutch Civil Code. See in more detail and with a focus on the IRBC context Enneking and Heesakkers, above n. 35; Enneking et al., above n. 35, at 105-10. Note that the Dutch company law provisions do not provide much guidance on what specific tasks (the members of) corporate boards are supposed to execute. Arts. 2:141 / 2:251 Dutch Civil Code suggest that those tasks include developing a company strategy, gaining insight into the general and financial risks of the company, and making sure that the company has an administrative and audit system in place.

38. See also J. Veldman and M. Lokin, 'The Potential of the Dutch Corporate Governance Model for Sustainable Governance and Long Term Stakeholder Value', 2019/4 Erasmus Law Review (2019).

39. Monitoring Commissie Corporate Governance Code (2016) De Nederlandse Corporate Governance Code, mccg.nl/download/?id=3364.

40. Ibid., p. 8 .

41. Art. 2:8 Dutch Civil Code and Dutch Supreme Court, 4 April 2014, ECLI:NL:HR:2014:797 (Cancun)

42. Although there is no specific statutory provision to this effect, it is generally assumed that directors have a duty to obey relevant statutory rules, even if not doing so could be in the interest of the company. See, for instance, De Roo 2018. Furthermore, in managing the company the directors are subject to any restrictions flowing from the company's articles of incorporation. See, for instance, Arts. 2:129(1) / 2:239(1) Dutch Civil Code. 
'external' stakeholders who are not directly involved in or linked to the corporation's business activities, like most stakeholders in the IRBC context (i.e. employees of subsidiaries or subcontractors, host country communities, the local environment). ${ }^{43}$ Consequently (supervisory) directors are only required (or, strictly speaking, permitted) to take the interests of such 'external' stakeholders into account if and to the extent that this is required by the law, follows from the company's articles of incorporation, or is in the company's own interest. ${ }^{44}$ An interesting development in this respect is a recent call by 25 Dutch company law professors for legislative change that would, among other things, extend directors' duties to encompass a responsibility for responsive corporate citizenship. ${ }^{45}$

It should be noted that even if a duty can be said to exist under certain circumstances for (supervisory) directors of Dutch companies to take the interests of stakeholders in the IRBC context into account, Dutch company law does not provide them with enforcement mechanisms to hold (officers of) the corporation liable for any damage suffered as a result of its operations. This also explains why there is no case law in the field of Dutch company law that specifically deals with irresponsible business conduct in global value chains. ${ }^{46}$ In theory, inquiry proceedings (the Dutch enqueteprocedure ${ }^{47}$ ) could provide an option for 'external' intervention in order to address serious and ongoing violations of human rights or environmental standards by Dutch companies (and/or their subsidiaries), as such proceedings may be instituted in the general interest by, for example, trade unions or the advocate general at the Dutch Supreme Court. ${ }^{48}$ Still, there are no recent examples of this being applied in the IRBC context. ${ }^{49}$ Another option would be to hold (supervisory) directors liable for damage suffered as a result of the company's operations on the basis of tort law. ${ }^{50}$ However, the threshold for this type of 'external' directors' liability is relatively high, ${ }^{51}$ which may explain

43. See also Enneking and Heesakkers, above n. 35; Enneking et al., above n. 35, at 105-10.

44. Enneking et al., above n. 35, at 103-17. The latter may occur if there is a business case for fair and sustainable production (as with green energy or slave-free chocolate), but also if preventing negative impacts is a matter of risk management owing to the threat of legal or reputational penalties.

45. Seeeur.nl/esl/nieuws/hoogleraren-ondernemingsrecht-bepleiten-deversterking-van-de-maatschappelijke-inbedding-van.

46. For a more detailed discussion including references to case law that may be indirectly relevant, see Enneking et al., above n. 35, at 102-40.

47. Art. 2:344 Dutch Civil Code et seq.

48. Enneking et al., above n. 35, at 117-33.

49. One case that may be mentioned here is the 1979 Batco case (Amsterdam Court of Appeals (Enterprise Division), 21 June 1979, NJ 1980, 71), which involved inquiry proceedings into the affairs of the company Batco Nederland, following a dispute between the company and the labour unions over the company's decision to close one of its factories in the Netherlands.

50. Art. 6:162 Dutch Civil Code.

51. A director can only under exceptional circumstances be held liable, next to the company, for damage caused by the company's activities. In order for director's liability to arise in this context, it needs to be established that there is serious personal blame on the director relating to the misconduct in question. See, for instance, Dutch Supreme Court, 8 December 2006, NJ 2006/659 (Ontvanger/Roelofsen); Dutch why none of the IRBC-related civil liability cases against companies that have been brought before Dutch courts (see para. 3.3) have included claims against (supervisory) directors individually.

A second starting point in Dutch company law that may over time lead to the development of IRBC-related duties of care may be found in the doctrine of liability in corporate groups. In the field of Dutch company law, the notions of separate legal personality and limited liability are seen as fundamental, meaning that, in principle, legal persons cannot be held liable for the actions of other legal persons. These notions also apply to corporations belonging to the same group; from a legal point of view they are viewed as separate entities and may therefore be held liable for debts or actions of other group entities only in exceptional cases. ${ }^{52}$ However, there is a relevant line of case law in which Dutch parent companies of corporate groups have been held liable for breaching duties of care owed to their subsidiaries' creditors. These cases have not been based on veil piercing doctrines, but on the Dutch general provision on noncontractual liability (tort). In each of these cases, the parent company was assumed to have insight into and control over the subsidiary's harmful activities owing to its intensive involvement in (relevant aspects of) the management of that subsidiary. ${ }^{53}$

All of these cases have so far revolved around parent company duties of care towards voluntary creditors of subsidiaries who have suffered financial harm owing to the parent company's acts or omissions; there have not yet been any cases relating to human rights or environmental factors and/or to global value chains. Still, there does not seem to be any reason why similar duties could not be accepted under Dutch tort law in relation to involuntary (tort) creditors like host country workers, neighbours and communities who suffer personal injuries or other types of harm as a result of human rights violations and/or environmental degradation. If anything, under Dutch tort law the threshold for liability is likely to be lower in cases involving personal injuries and/or involuntary creditors than in those involving commercial parties and purely financial interests. ${ }^{54}$ And sure enough, in the footsteps of similar cases before US and English courts a number of cases have been brought before Dutch courts in which attempts have been made to hold Netherlands-based parent companies liable for the detrimental human rights or environmental impacts

Supreme Court, 23 November 2012, NJ 2013/302 (Spaanse Villa); Dutch Supreme Court, 5 September 2014, NJ 2015/21 (Hezemans Air); Dutch Supreme Court, 5 September 2014, NJ 2015/22 (RCI/Kastrop); Dutch Supreme Court, 6 Februari 2015, ECLI:NL:HR:2015:246 (Crane/ Staal).

52. Enneking et al., above n. 35 , at 126-31

53. Well-known cases include the following: Dutch Supreme Court 25 September 1981, NJ 1982, 443 (Osby/LVM); Dutch Supreme Court 19 February 1988, NJ 1988, 487 (Albada Jelgersma II); Dutch Supreme Court 12 June 1998, NJ 1998, 727 (Coral/Stalt); Dutch Supreme Court 11 September 2009, JOR 2009, 309 (Comsys)

54. See, in more detail, Enneking et al., above n. 35, at 175-7. See also L. Enneking, Foreign Direct Liability and Beyond (2012), at 235-8 and C. Van Dam, Onderneming en mensenrechten (2008) 55-63, 67. 
of their foreign subsidiaries' activities in host countries (see in more detail para. 3.3).

A third starting point in Dutch company law that may, over time, foster the development of IRBC-related duties of care comes from transparency obligations. Under Dutch company law, Dutch companies are under an obligation to report on certain non-financial performance indicators, including environmental and personnel issues, in the management report that is drawn up by the corporation's board of directors on a yearly basis. ${ }^{55}$ This transparency obligation applies only if and to the extent that reporting on such indicators is required for a good understanding of the development, and the results or the position of the business enterprise, and does not apply to small business enterprises. Directive 2014/95/EU relating to the disclosure of non-financial and diversity information ${ }^{56}$ extends this requirement by introducing an obligation for certain large business enterprises to report on their business policies relating to the environment, social and personnel issues, human rights and the combat of corruption and bribery, as well as on the impacts of those policies. If the business enterprise does not pursue a policy on one or more of these subjects, it is to include a clear and reasoned explanation for not doing so. ${ }^{57}$ In the aforementioned proposal by Dutch company law professors it is suggested that the existing transparency obligations should be extended to include the way company directors have discharged their responsibility for responsive corporate citizenship. ${ }^{58}$

As these transparency obligations do not create any direct duties vis-à-vis host country workers, neighbours or communities who may be negatively impacted by the human rights or environmental impacts of the business enterprises concerned, they cannot be enforced by them. As a result, the enforcement of these transparency obligations under Dutch company law is mainly in the hands of shareholders and investors, who may hold the company's directors liable for damage they have suffered as a result of misleading information in the management report. ${ }^{59}$ There is also a possibility, in theory at least, for the enterprise division of the Amsterdam court of appeal to take action at the instigation of certain stakeholders (like the company's works council but also competitors, creditors and civil society organisations) by ordering the company to adjust a management report that is not in conformity with the law. ${ }^{60}$ Furthermore, the Dutch public prosecutor may institute criminal proceedings on account of violation of these obligations; ${ }^{61}$

55. Art. 2:391 Dutch Civil Code.

56. Directive 2014/95/EU of the European Parliament and of the Council of 22 October 2014 amending Directive 2013/34/EU as regards disclosure of non-financial and diversity information by certain large undertakings and groups, O.J. L330/1 (15 November 2014).

57. The Directives' obligations have been implemented in Dutch law and have been made applicable from the financial year of 2017 onwards: Besluit bekendmaking niet-financiële Informatie, Stb. 2017, 100.

58. See above n. 45.

59. Art. 2:139 and 2:249 Dutch Civil Code.

60. Art. 2:447 Dutch Civil Code et seq.

61. Art. 1(4) Dutch Economic Offences Act (Wet Economische Delicten) as this is regarded as a minor offence, however, the prosecution interests will not be substantial, and a resulting conviction is not likely to have a strong normative effect. ${ }^{62}$

Although these transparency obligations do not in themselves require companies to take into account the IRBCrelated interests of third-party stakeholders - as they merely require them to report on the policies they have in this respect - they do allow company stakeholders to factor the company's performance on relevant nonfinancial aspects into their decision whether and how to engage with it. This is relevant since in the absence of concrete duties of care, the current role of Dutch company law in protecting IRBC-related interests depends largely on the possibilities for and readiness of shareholders and investors to take action on IRBC-related issues, including through agenda setting of and voting at shareholders' meetings. Despite some of the thresholds to active participation that exist under Dutch company law, ${ }^{63}$ the readiness to take action on IRBC-related issues seems to be increasing, especially among Dutch institutional investors. ${ }^{64}$ This development is being spurred on by the IRBC covenants, in particular those with the Dutch insurance sector ${ }^{65}$ and the Dutch pension funds, ${ }^{66}$ which focus specifically on sustainable investment and require active engagement with investee companies on IRBC issues. The same is true for the expanding regulatory framework relating to sustainable investment at the EU level, which reinforces the role of IRBC-related soft law frameworks like the UNGPs and the OECD Guidelines also in relation to the financial sector.

\subsection{Relevant Aspects of Dutch Tort Law}

Unlike Dutch company law, Dutch tort law is specifically geared towards protecting third parties' interests against the harmful effects caused by the activities of others, including corporate actors, as it may be invoked at the initiative of an injured party in order to obtain relief in relation to the (potential) damage suffered from those responsible. As such, it is an obvious potential source of IRBC-related duties of care for Netherlandsbased companies. As mentioned, Dutch courts have, over the past few years, been confronted with a number of cases in which IRBC stakeholders have sought to hold Netherlands-based parent companies liable for the detrimental human rights or environmental impacts of their foreign subsidiaries' activities in host countries. These cases form part of a broader trend towards for-

62. Enneking et al., above n. 35, at 126.

63. See, for instance, Art. 2:114a Dutch Civil Code, which requires support from at least $3 \%$ of the issued share capital in order for shareholders to be allowed to request discussion of a certain issue at the General Meeting of a Dutch public limited company.

64. See also: Enneking and Heesakkers, above n. 35; Enneking et al., above n. 35 , at 122 .

65. See, for more information on and the text of the Agreement for, international responsible investment in the insurance sector: imvoconvenanten.nl/en/insurance.

66. See, for more information on and the text of the Agreement for the Pension Funds: imvoconvenanten.nl/en/pension-funds. 
eign direct liability cases: transnational civil liability claims brought against Western society-based parent companies of multinational enterprises in relation to the detrimental human rights and/or environmental impacts of the activities of their subsidiaries, subcontractors or business partners in host countries. ${ }^{67}$

The first case of this kind to be brought before Dutch courts pertained to claims by a number of Nigerian farmers and the Dutch NGO Milieudefensie against Royal Dutch Shell (RDS) and its Nigerian subsidiary Shell Petroleum Development Company of Nigeria (SPDC) in relation to various oil spill incidents from SPDC-operated pipelines in the Niger Delta. ${ }^{68}$ In January 2021, the Hague court of appeal reached a verdict on the merits ordering SPDC to pay compensation to the farmers for the damage they suffered as a result of the oil spills and ordering both SPDC and parent company RDS to install equipment to prevent or mitigate future oil spill-related damage. ${ }^{69}$ In another case against Shell that is currently pending before the Hague District Court, widows of Nigerian environmental activists seek reparation for harm suffered as a result of Shell's alleged involvement in human rights violations perpetrated in Nigeria in the mid-1990s ${ }^{70}$ Furthermore, a group of citizens from the Ivory Coast are pursuing claims against the Anglo-Dutch petroleum trading company Trafigura for its involvement in the Probo Koala waste dumping incident in Abidjan in 2006. ${ }^{71}$ In April 2020, the Amsterdam court of appeal ruled in favour of the plaintiffs by overturning an earlier dismissal of the case by the district court on procedural grounds; defendant company Trafigura has filed an appeal in cassation against this ruling. ${ }^{72}$

Such cases relating to irresponsible business conduct in global value chains typically relate to corporate activities in weak governance zones, where legal standards relating to the protection of human rights, health and safety and the environment are not very strict and/or poorly enforced. As a result, the focus in these foreign direct liability cases is generally on holding the corporate actors involved liable for violations of unwritten norms pertaining to due care in relation to the interests of third-party stakeholders. ${ }^{73}$ In Dutch tort law, such claims may be based on the open standard of ' $\ldots$ an act

67. Enneking et al., above n. 35, at 217-22, 256-8; Enneking, above n. 54.

68. See, in more detail, L. Enneking, 'Transnational Human Rights and Environmental Litigation - A Study of Case Law Relating to Shell in Nigeria', in I. Feichtner, M. Krajewski \& R. Roesch (eds.), Human Rights in the Extractive Industries - Transparency, Participation, Resistance (2019) 511-51.

69. The Hague Court of Appeal, 21 January 2021, ECLI:NL:GHDHA: 2021:132 (Fidelis Ayoro Ugura et al. v. Royal Dutch Shell plc and Shell Petroleum Development Company of Nigeria Ltd).

70. See, in more detail, Enneking, above n. 68.

71. See, in more detail, Enneking et al., above n. 35, at 93-9.

72. Amsterdam Court of Appeal 14 April 2020, ECLI:NL:GHAMS: 2020:1157 (Stichting Victimes des Dechets Toxiques de Cote d'Ivoire v. Trafigura Beheer B.V., Trafigura Limited). See alsobeeradvocaten.com/en/News/News-and-current-events/article/ 988/Ruling-on-appeal-on-Probo-Koala-toxic-waste-dump.

73. The following is largely derived from Enneking et al., above n. 35, at 162-96. or omission in violation ... of what according to unwritten law has to be regarded as proper societal conduct', which is laid down in Article 6:162 of the Dutch Civil Code. ${ }^{74}$ It opens up the possibility to include generally accepted, non-binding standards of conduct in assessing the measure of care that could have been expected of the companies involved. Thus, behavioural norms that flow from the UNGPs and the OECD Guidelines, including the corporate responsibility to prevent, mitigate and/or redress the negative effects on third parties of operations pursued by or for them, may through this open standard become part of judicially articulated, legally binding IRBC-related duties of care. If those duties are considered to have been violated, this gives rise to a right to remedy for the third-party stakeholders involved. ${ }^{75}$

Through this open standard, Dutch tort law also offers the possibility to hold a company liable for harm that is caused not by its own activities but by those of others, such as foreign subsidiaries, subcontractors or other companies in their global value chains. Determining factors are the degree to which the IRBC risks related to these activities could have been foreseeable for the company and the degree to which it could have prevented or restricted those risks on the basis of its de facto influence on the relevant actors and activities. In practice, case law relating to parent company liability under Dutch tort law has so far remained confined to the aforementioned cases involving duties of care towards voluntary creditors of subsidiaries that have suffered financial harm owing to the parent company's acts or omissions (see para. 3.2). However, as mentioned, there is no reason why similar duties could not be accepted in relation to involuntary (tort) creditors like host country workers, neighbours and communities who suffer personal injuries or other types of harm as a result of human rights violations and/or environmental degradation. ${ }^{76}$

In the case between the Nigerian farmers and Milieudefensie against Shell, the Hague court of appeal had already briefly addressed the issue of parent company liability in a 2015 interim judgment, holding that it had jurisdiction over both the claims against RDS and those against SPDC and dismissing Shell's argument that the claims against the parent were evidently without merit. ${ }^{77}$ It stated:

Considering the foreseeable serious consequences of oil spills to the local environment from a potential spill source, it cannot be ruled out from the outset that the parent company may be expected in such a case to take an interest in preventing spills (or in other words, that there is a duty of care ...), the more so if it has made the prevention of environmental

74. Art. 6:162(2) Dutch Civil Code

75. See, in more detail, Enneking et al., above n. 35, at 229-52.

76. See, in more detail and with further references to case law, Enneking, above n. 68; Enneking et al., above n. 35, at 162-81; Enneking, above n. 54 , at 229-38

77. The Hague Court of Appeal, 18 December 2015, ECLI:NL:GHDHA: 2015:3586, ECLI:NL:GHDHA:2015:3587, ECLI:NL:GHDHA:2015:3588. 
damage by the activities of group companies a spearhead and is, to a certain degree, actively involved in and managing the business operations of such companies, which is not to say that without this attention and involvement a violation of the duty of care is unthinkable and that culpable negligence with regard to the said interests can never result in liability. ${ }^{78}$

In its 2021 decision on the merits, the court decided with respect to one of the spill sites at issue that RDS alongside its subsidiary SPDC - owed a duty of care to the people living in the vicinity of the pipeline to ensure that a leak detection system (LDS) would be installed so as to prevent or mitigate future oil spill-related damage. In coming to this decision, the court drew on the decision by the UK Supreme Court in the Vedanta case, in which it was held that in determining whether such a duty of care for the parent company exists,

[e]verything depends on the extent to which, and the way in which, the parent availed itself of the opportunity to take over, intervene in, control, supervise or advise the management of the relevant operations ... of the subsidiairy. ${ }^{79}$

On the basis of the available evidence, the Hague court of appeal found that at least from 2010 onwards, RDS had concretely and rather intensively interfered with the question of whether the Nigerian pipelines, including the one that was the source of one of the spills, ought to be equipped with an LDS. It concluded that the fact that this pipeline had to date still not been equipped with such a device constituted negligence not only by SPDC but, considering the parent company's knowledge of the local circumstances and involvement in its subsidiary's relevant processes, also by RDS. ${ }^{80}$

It has to be noted that the decision by the Hague court of appeal does not deal with parent company liability for (ir)responsible business conduct in global value chains under Dutch tort law. In fact, more generally speaking, the role of Dutch tort law in foreign direct liability cases before Dutch courts is limited because under the current conflict-of-laws regime (the Rome II Regulation), home country (i.e. Dutch) tort law would only be applicable to substantive issues of liability by way of exception. ${ }^{81}$ Still, as is evidenced by the court's January 2021 decision, this does not necessarily keep Dutch courts from articulating IRBC-related duties of care in cases brought before them, even on the basis of host country tort law. At the same time, it is likely that application of

78. The Hague Court of Appeal, 18 December 2015, ECLI:NL:GHDHA: 2015:3586 (para. 3.2), ECLI:NL:GHDHA:2015:3587 (para. 2.2), ECLI:NL:GHDHA:2015:3588 (para. 2.2).

79. Vedanta Resources PLC and another (Appellants) $\vee$ Lungowe and others (Respondents), [2019] UKSC 20.

80. The Hague Court of Appeal, 21 January 2021, above n. 69, para. 7.

81. Art. 4 (1) Rome II Regulation. See, in more detail, Enneking, above n. 68; L. Enneking, 'Applicable Law', in J.J. Álvarez-Rubio and K. Yiannibas (eds.), Human Rights in Business - Removal of Barriers to Access to Justice in the European Union (2017) 48-61; Enneking et al., above n. 35 , at $151-8$
Dutch tort law would lead to comparable results with regard to the question of whether and under what circumstances a parent company may owe a duty of care towards third parties that are or stand to be negatively affected by its subsidiary's host country activities. ${ }^{82}$

\subsection{Discussion}

From a legal perspective, the CLDD Act is highly relevant as it introduces an IRBC-related due diligence obligation that has no precedent in Dutch law. The importance of such an obligation is underlined by a 2019 study indicating that only one-third of even the largest Dutch companies had at that time endorsed the UNGPs and/or the OECD Guidelines as a frame of reference for their international activities. ${ }^{83}$ One way or another, the CLDD Act is bound to change this status quo as it will affect the IRBC policies and corporate practices of the companies it covers. Of course, the impact of the Act in this respect is limited by some of its main features, including its material scope (limited to child labour) and its personal scope (limited to companies supplying goods or services to Dutch end users). Even so, the companies that it does cover will have no choice but to conduct due diligence with respect to the relevant goods and services in accordance with the guidelines that are yet to be set out through secondary legislation. Furthermore, the fact that the Act includes exemptions for companies buying goods or using services from suppliers that themselves comply with its provisions may well have the effect of promoting due diligence in accordance with the CLDD Act's standards also among other companies in the supply chain. Similarly, the exemption for companies conducting due diligence in accordance with government-approved action plans is prone to stimulating the uptake of multistakeholder initiatives to this effect, like the IRBC agreements.

Next to an IRBC-related due diligence obligation, the CLDD Act also introduces a public law supervisor that is to monitor and enforce compliance with the Act. Although the supervisor will operate on a complaints basis only, the range of potential complainants is broad, and so is the bandwidth of the administrative fines that the supervisor can impose in case of non-compliance. What still remains unclear is whether the task of supervising compliance with the CLDD Act will be taken on by an existing body like the Authority for Consumers \& Markets or the Dutch National Contact Point or whether it will require the establishment of a new, dedicated supervisor. Similarly, the supervisor's modus operandi is yet to be worked out in further detail through secondary legislation. Research has suggested

82. See, in more detail, Enneking et al., above n. 35

83. A study conducted by Ernst\&Young in late 2019 showed that despite the Dutch government's policy commitment that in $202390 \%$ of the (around 700) largest companies in the Netherlands should endorse the OECD Guidelines as the frame of reference for their international activities, only $35 \%$ of the 723 companies in the reference group endorsed the OECD Guidelines and/or the UNGPs. See 'Monitoringsproject onderschrijving OESO richtlijnen en UNGPs' (April 2020), rijksoverheid.nl/documenten/publicaties/2020/04/03/ monitoringproject-onderschrijving-oeso-richtlijnen-en-ungps. 
that the enforcement of Dutch legislation in the IRBC context should take the shape of 'dynamic supervision', which '...can be compared to what is known as "experimentalist governance", which involves both supervisors and supervised companies, as well as their stakeholders, in innovating regulation and supervision'. Although '[e]xamples in the framework of OECD due diligence do not (yet) exist', it 'is already partly used in other areas of supervision'. ${ }^{84}$ In a recent policy brief the minister concerned has indicated that this type of supervision will also be considered when developing the particulars of the CLDD Act. ${ }^{85}$

Still, whereas the CLDD Act does arguably represent an important step forward in Dutch law when it comes to the legal implementation of IRBC-related due diligence, it does nothing to improve access to remedies for the actual victims of child labour in accordance with the UNGPs' third pillar. They would remain dependent on the possibilities offered by existing norms in Dutch company law and/or Dutch tort law that give rise to duties of care owed by companies to third-party stakeholders in the IRBC context. At present, the best option for victims of IRBC violations seeking legal remedies for the harm they have suffered as a result of corporate activities by or for Dutch companies would be to initiate civil liability procedures before Dutch courts against the companies involved. The recent judgment by the Hague court of appeal in the case between Nigerian farmers and Shell shows that civil liability claims brought before Dutch courts by victims of IRBC violations resulting from activities undertaken by or for Dutch companies can be successful. It should be noted that in the particular case of child labour, victims bringing such claims may benefit from the fact that Dutch criminal law features a relatively broad provision on corporate involvement in modern slavery, including child labour, which could be relied on in formulating the civil law duty of care allegedly breached by the companies involved. ${ }^{86}$

84. C. Van Dam and M. Scheltema, 'Opties voor afdwingbare IMVOinstrumenten' (3 April 2020), rijksoverheid.nl/documenten/publicaties/ 2020/04/03/opties-voor-afdwingbare-imvo-instrumenten, pp. 95-96, 102. See, for the English language version, government.nl/documents/ publications/2020/04/21/options-for-enforceable-irbc-instruments.

85. Brief van de Minister voor Buitenlandse Handel en Ontwikkelingssamenwerking, 16 October 2020, Kamerstukken // 2020-21, 26485, nr. 337.

86. Art. $273 \mathrm{f}$ of the Dutch criminal code may, in principle, be relied on to hold companies criminally liable for their involvement in child labour, even if the involvement has been indirect in that they have profited (in the Netherlands) from the exploitation in question by other companies in the value chain, rather than directly engaging in such exploitation. In practice, however, this provision is rarely enforced by Dutch public prosecutors, as is evidenced by the fact that only very few modern slavery-related cases against corporate defendants have made their way into Dutch criminal courts so far; of the cases that did, none involved prosecution of a company for its direct or indirect involvement in child labour. As a consequence, the role of this provision remains limited, for now at least, to providing a potential additional yardstick for victims of child labour seeking access to remedy through transnational civil liability claims before Dutch courts. See, in more detail, A. Schaap, 'Legally Binding Duties for Corporations Under Domestic Criminal Law Not to Commit Modern Slavery', in L. Enneking, I. Giesen, A. Schaap, C. Ryngaert, F. Kristen \& L. Roorda (eds.), Accountability, International Business Operations, and the Law (2020) 192-16, at 202; A. Schaap, De
From a policy perspective, the CLDD Act also holds relevance, as it has ensured that the Dutch government, despite its strong preference for non-binding measures in the IRBC context, cannot get around the introduction of some form of mandatory due diligence legislation. Until recently, the main focus of the Dutch government's IRBC policy was on multistakeholder initiatives, particularly the IRBC sector agreements. Along with the recent critical evaluation of the effectiveness of these agreements, the introduction and subsequent adoption of the CLDD Act has undoubtedly played a role in the Dutch government's recent change of course in this respect. As a result, the current Dutch IRBC policy now advocates the 'smart mix' of regulatory instruments that many experts in the field, including John Ruggie himself, ${ }^{87}$ believe to be necessary in order to bring about IRBC in global value chains, with mandatory due diligence a necessary part of the mix. ${ }^{88}$ This means, whether in the form of the CLDD Act, of due diligence legislation with a broader material scope, or of an EUwide due diligence obligation, due diligence will become mandatory for (some) companies in the Netherlands, one way or another. At the same time, the inevitability of some form of mandatory due diligence in the Netherlands provides an incentive for the Dutch government to lobby in favour of a meaningful EU-wide instrument.

\section{International Relevance}

\subsection{Introduction}

Whereas the due diligence obligation that the CLDD Act introduces into Dutch law with respect to IRBC in global value chains is new to Dutch law, it is not without precedent from an international perspective. Similar obligations have been introduced or are being seriously considered in many other European countries as well as at the EU level. Generally speaking, these legislative initiatives can be said to fall into one of three categories: 1) mandatory disclosure legislation; 2) mandatory due diligence legislation; or 3) duty of care legislation. ${ }^{89}$

The first category comprises legislation imposing a requirement for companies to disclose information regarding their human rights and/or environmental impacts and/or the policies they have in place to deal with those impacts. An example is the 2015 UK Mod-

strafrechtelijke aansprakelijkheids van ondernemingen voor moderne slavernij (2017); Enneking et al., above n. 35.

87. Ministerie van Buitenlandse Zaken, 'Van voorlichten tot verplichten Een nieuwe impuls voor internationaal maatschappelijk verantwoord ondernemerschap', above n. 31, p. 24-30. See also Brief van de Minister voor Buitenlandse Handel en Ontwikkelingssamenwerking, 16 October 2020, Kamerstukken I/ 2020-21, 26485, nr. 337.

88. Commentary to Principle 3 UNGPs.

89. See also, albeit with a slightly different categorisation, N. Bueno, 'The Swiss Popular Initiative on Responsible Business: From Responsibility to Liability', in L. Enneking, I. Giesen, A. Schaap, C. Ryngaert, F. Kristen \& L. Roorda (eds.), Accountability, International Business Operations, and the Law (2020) 239-58; N. Bueno and C. Bright, 'Implementing Human Rights Due Diligence Through Corporate Civil Liability', 69 International \& Comparative Law Quarterly 789 (2020). 
ern Slavery Act, which, among other things, includes a requirement for companies covered by the Act to issue a yearly statement on (the risk of) slavery and human trafficking in their supply chains and on the risks taken to address that risk. ${ }^{90}$ Another example of this type of legislation is the aforementioned EU Non-Financial Reporting Directive, which requires large companies to publish information on their policies with respect to, among other things, environmental protection and respect for human rights, including due diligence procedures, throughout the value chain aimed at addressing negative effects in this context. ${ }^{91} \mathrm{~A}$ similar disclosure requirement is soon to be introduced in Swiss law, as part of a counterproposal that was adopted by the Swiss parliament in 2020 in response to a popular bid to introduce duty of care legislation in relation to the human rights and environmental impacts of Switzerland-based companies and of companies operating in their global value chains. ${ }^{92}$

The second category comprises legislation imposing a requirement for companies to conduct due diligence with respect to their human rights and/or environmental impacts, including those that occur in their global value chains. The Dutch CLDD Act is an example of this type of legislation. Other examples include the EU Timber Regulation, ${ }^{93}$ which introduces a due diligence obligation for EU traders who place timber products on the EU market for the first time, and the EU Conflict Minerals Regulation, ${ }^{94}$ which introduces a due diligence obligation for EU importers of tin, tungsten, tantalum and gold. In this type of legislation, monitoring and enforcement is typically left to public authorities, through administrative or criminal procedures and/or (as is the case with the CLDD Act) a combination of both. What is absent in these legislative initiatives is an enforcement mechanism providing access to remedies for those suffering harm as a result of the human rights or environmental impacts involved.

The third category comprises legislation imposing mandatory due diligence in combination with civil liability in case of violation of the due diligence standard set out. An example is the 2017 French Duty of Vigi-

90. Modern Slavery Act 2015, legislation.gov.uk/ukpga/2015/30/contents/ enacted.

91. See above n. 56

92. See, for instance, I. Hammerschmid and M. Vesper-Gräske, 'Down But Not Defeated: What's Next for Swiss Human Rights Due Diligence?' (15 December 2020), lexology.com/library/detail.aspx?g=ed6e8e0ad97b-4a50-8334-a7c23292f955; J. Reardon and T. Navarro, 'The Dawn of Human rights due diligence in Switzerland?', The FCPA Blog (7 December 2020), fcpablog.com/2020/12/07/the-dawn-of-humanrights-due-diligence-in-switzerland/. See also Bueno, above n. 89.

93. Regulation (EU) No 995/2010 of the European Parliament and of the Council of 20 October 2010 laying down the obligations of operators who place timber and timber products on the market Text with EEA relevance, O.J. L295/23, 12 November 2010

94. Regulation (EU) $2017 / 821$ of the European Parliament and of the Council of 17 May 2017 laying down supply chain due diligence obligations for Union importers of tin, tantalum and tungsten, their ores, and gold originating from conflict-affected and high-risk areas, O.J. L130/1, 19 May 2017. lance Law, ${ }^{95}$ which requires certain large French companies to establish and implement a vigilance plan to prevent human rights violations and environmental damage arising from the operations of its subcontractors or suppliers and provides that the companies involved can be held civilly liable for harm that would not have occurred if the company would have had a proper vigilance plan in place. Characteristic of this type of legislation is that it combines provisions rendering key components of the corporate duty to protect (as set out in the second pillar of the UNGPs) legally binding, with provisions enabling access to judicial remedies for victims of corporate violations of human rights (as set out in the third pillar of the UNGPs) or the environment.

\subsection{The CLDD Act in Comparative Perspective}

The question arises as to how the CLDD Act compares with similar legislative initiatives aimed at promoting responsible business conduct in global value chains in other European countries and at the EU level. Also in view of the scope and aim of this article, the comparison will be limited to the aforementioned French Duty of Vigilance Law - since this is the only other mandatory due diligence law to have been adopted so far - and the outline for a future EU directive on corporate due diligence and corporate accountability set out in an EP resolution that was adopted in March $2021^{96}$ - since the possible adoption of such legislation will determine whether the CLDD Act will actually see the light of day. The comparison will focus on many key aspects: personal scope (i.e. companies covered); material scope (i.e. issues covered); main obligations; ambit (i.e. companies in the value chain the activities of which are covered); enforcement; remedies; and potential impact (i.e. the potential for engendering responsible business conduct in the value chain). The aim of the comparison is to determine which of the CLDD Act's key features, if any, stand out in comparison with the other two initiatives. The outcome of the analysis will provide a basis for a discussion of whether the Act can be considered relevant also internationally.

\subsubsection{Personal Scope}

As discussed in para. 2.1, the CLDD Act's personal scope extends to every company that supplies goods or services to Dutch end users and, as such, covers both companies registered in the Netherlands and those registered outside of the Netherlands. Although the Act, in principle, covers companies of all sizes and from all sectors, it contains a provision that certain categories of companies can be exempted by council order, which may yet be relied on to exempt, for instance, small and medium-sized companies (SMEs) or companies from low-risk sectors.

95. LOI n² 2017-399 du 27 mars 2017 relative au devoir de vigilance des sociétés mères et des entreprises donneuses d'ordre, legifrance.gouv.fr/ jorf/id/JORFTEXT000034290626/.

96. Corporate due diligence and corporate accountability, European Parliament resolution of 10 March 2021 with recommendations to the Commission on corporate due diligence and corporate accountability (2020/2129(INL)), P9_TA-PROV(2021)0073. 
The Duty of Vigilance Law applies only to corporations registered in France that employ, at the end of two consecutive years, at least a) 5,000 employees themselves and in their direct and indirect subsidiaries with registered offices in France or b) 10,000 employees themselves and in their direct and indirect subsidiaries with registered offices in France or abroad. ${ }^{97}$ There is no formal list of companies that are subject to the Law, ${ }^{98}$ but, according to research by French NGOs, at least 260 companies fall within its personal scope. ${ }^{99}$ Although the Law covers only French companies, it should be noted that French subsidiaries of foreign holding companies may also be covered by the law, provided the subsidiary employs the threshold number of employees. ${ }^{100} \mathrm{~A}$ company is exempted if it is a subsidiary of or controlled by a company that itself establishes and implements a vigilance plan covering both its own activities and those of its subsidiaries or companies it controls. ${ }^{101}$

The outline proposed by the European Parliament for a future due diligence directive in a sense combines the approaches of the CLDD Act and the Duty of Vigilance Law, as it applies not only to European companies (i.e. governed by the law of a member state or established in the territory of the Union), but also to non-European companies that sell goods or provide services in the EU internal market. With respect to the first category, its reach is limited to a) large undertakings; b) publicly listed SMEs; and c) SMEs operating in high-risk sectors. Accordingly, small and medium-sized European companies that are not publicly listed and that do not operate in high-risk sectors are exempted. ${ }^{102}$

\subsubsection{Material Scope}

The material scope of the CLDD Act is limited to child labour, which is defined in the Act along the lines of ILO Conventions C138 (the Minimum Age Convention 1973) and C182 (the Worst Forms of Child Labour Convention 1999). ${ }^{103}$ The Duty of Vigilance Law, by contrast, encompasses risks to or negative impacts on a much broader range of matters, including: a) human rights and fundamental freedoms, b) health and safety of persons and c) the environment. ${ }^{104}$ These concepts are not defined in the law itself and/or by reference to existing national or international norms pertaining to

97. Art. L.225-102-4.-I French Commercial Code. See also, in more detail, E. Savourey, 'French Country Report', in Study on Due Diligence Requirements Through the Supply Chain - Part III: Country Reports (20 February 2020), op.europa.eu/en/publication-detail/-/publication/ 0268dfcf-4c85-11ea-b8b7-01aa75ed71a1/language-en, p. 56-94 at 60-61.

98. A. Schilling-Vacaflor, 'Putting the French Duty of Vigilance Law in Context: Towards Corporate Accountability for Human Rights Violations in the Global South?', 22 Human Rights Review 109, at 116 (2021).

99. See the 'duty of vigilance radar' at vigilance-plan.org/search (last accessed 15 March 2021).

100. Savourey, above n. 97 , at 63.

101. Art. L.225-102-4.-I para. 2 French Commercial Code. See also Savourey, above n. 97 , at 61

102. Art. 2 EP outline.

103. Art. 2 CLDD Act.

104. Art. L. 225-102-4.-I para. 3 French Commercial Code. See also Savourey, above n. 97 , at 62 these issues. ${ }^{105}$ Although not mentioned specifically in its provisions, issues pertaining to climate change issues are also assumed to fall within the material scope of the law. ${ }^{106}$ The outline proposed by the EP for a future due diligence directive has an even broader scope as it covers human rights, the environment (including climate change mitigation) and good governance. ${ }^{107}$ All three concepts will eventually be defined in separate annexes, which are to be reviewed on a regular basis and should be consistent with the EU's objectives on these issues. ${ }^{108}$

\subsubsection{Main Obligations}

As discussed in para. 2.1, the CLDD Act's requirement that companies supplying goods or services to Dutch end users conduct due diligence with a view to preventing child labour from being used in the production of those goods and services is in fact its core obligation. The connected requirement that they have to file a declaration to this effect will remain of limited relevance if further requirements as to the form and content of this declaration stay out. The Act's due diligence obligation purports that the companies involved are expected to investigate whether there is a reasonable presumption that the goods or services in question have been produced with the help of child labour; where such a presumption exists, they are to draw up and carry out an action plan. The investigation needs to be based on sources that can reasonably be known to the company and that are accessible to it. Further requirements with respect to the scope and content of the investigation and the action plan are yet to be defined through secondary legislation. A company is assumed to have conducted due diligence with respect to certain goods or services if it buys or uses them from a supplier that has submitted a declaration with respect to those goods or services along the lines set out in the CLDD Act. If the company only buys or uses such goods or services, it is not required to issue a declaration itself.

The Duty of Vigilance Law is divided into three interconnected requirements: i) the companies covered by it are required to establish a vigilance plan; ii) they are required to effectively implement the vigilance plan and iii) they are required to make public both the plan and the report on its effective implementation. The vigilance plan is to be drawn up and made public on an annual basis. It should contain reasonable vigilance measures that are adequate to identify risks and prevent severe impacts on the subject matter within the material scope of the law resulting from the activities of the company itself and of certain other companies within its value chain (see 'reach'). It should contain five measures:

105. Savourey, above n. 97 , at $62-3$

106. Compare the 2020 report by Notre Affaire à Tous 'Benchmark de la vigilance climatique des multinationales', at notreaffaireatous.org/wpcontent/uploads/2020/03/Rapport-General-Multinationales-

NAAT-2020.02.01.pdf and see the statement of claim relating to a climate change case against Total by a number of French NGOs, which is primarily based on the Duty of Vigilance Law, at media.businesshumanrights.org/media/documents/files/Dossier_de_presse_EN.pdf

107. Art. 1(1) EP outline.

108. Art. 3(6)-3(8) EP outline. 
i) risk mapping, ii) regular evaluation processes; iii) adapted actions to mitigate risks or prevent severe impacts; iv) an alert and complaint mechanism and v) a system monitoring implementation measures and evaluating their effectiveness. The Law leaves open the option of the Conseil D'Etat issuing a decree in which these measures are worked out in more detail, but this has not happened yet. ${ }^{109}$

Also here, the outline proposed by the EP for a future due diligence directive in a sense combines the approaches of the CLDD Act and the Duty of Vigilance Law. Its point of departure is that undertakings should carry out effective due diligence with respect to potential or actual adverse impacts on the subject matter within the material scope of the EP outline in their operations and business relationships. They are required to make, in an ongoing manner, all efforts within their means to identify and assess whether their operations and business relationships cause or contribute to or are directly linked to any such impacts. If an SME or a large undertaking that only has direct business relationships domiciled within the EU concludes that this is not the case, it may publish a statement to that effect; such a conclusion is warranted, in particular, if all of the company's direct suppliers perform due diligence in line with the requirements set out in the EP outline. In all other cases, companies are required to establish and effectively implement a due diligence strategy that includes, among other things: i) specification of the potential or actual adverse impacts and the level of their severity, likelihood and urgency; ii) mapping of the value chain and public disclosure of relevant information in this respect; iii) adoption and indication of all proportionate and commensurate policies and measures with a view to ceasing, preventing or mitigating the impacts and iv) a prioritisation strategy if the company is not in a position to deal with all the impacts at the same time. ${ }^{110}$ The EP outline further requires the companies involved to make their due diligence strategy (or their no-impact statement and risk assessment) publicly available. ${ }^{111}$

\subsubsection{Ambit}

The ambit of the CLDD Act's main obligation to conduct due diligence is not limited to the activities of a defined range of companies; by consequence, it extends, in principle, to all business operations within the value chain. The only limitation in this respect is the aforementioned provision that the investigation to be conducted by the companies covered by the law as part of their due diligence needs to be based on sources that can reasonably be known to the company and that are accessible to it. Of course, it is still possible that the secondary legislation that is supposed to set further requirements with respect to the Act's main obligation will limit the range of business operations in the value

109. Art. L. 225-102-4.-I French Commercial Code. See also Savourey, above n. 97, at 64-5.

110. Art. 4 EP outline.

111. Art. 6 EP outline. chain that are to be covered by the investigation into possible use of child labour, which companies are required to conduct under the Act. It is questionable, however, whether this could be reconciled with its stated aim of ensuring that Dutch consumers can in good conscience purchase goods and services by preventing the use of child labour in their production.

The Duty of Vigilance Law has a more circumscribed ambit with regard to the business operations to be covered in the vigilance plan that companies falling within its personal scope are required to draw up. It should focus on the risks and severe impacts that may result from the activities of: i) the company itself; ii) the companies it directly or indirectly controls and iii) subcontractors and suppliers with whom there is an established commercial relationship, to the extent that the activities in question are related to this relationship. ${ }^{112}$ Control in this respect is a rather broad concept, since it may be understood as decision-making power, whether directly or indirectly, over the financial and operational policies of the controlled company and includes not only legal but also de facto and contractual control. ${ }^{113}$ The range of companies whose activities may have to be covered in the vigilance plan is extended even further by the Law's reference to subcontractors and suppliers. This is a potentially even much broader category owing to, among other things, the lack of a clear definition of 'suppliers', the possibility that this concept may also cover suppliers of controlled companies, and the questions raised by the 'established commercial relationship' criterion. ${ }^{114}$

The ambit of the business operations to be covered by the due diligence that companies falling within the personal scope of the outline proposed by the EP for a future due diligence directive are supposed to carry out is comparable to that of the Duty of Vigilance Law in the sense that it is circumscribed yet broad. The EP outline requires them to do so with respect to 'their operations and business relationships', ${ }^{115}$ defining the latter as 'subsidiaries and commercial relationships of an undertaking throughout its value chain, including suppliers and sub-contractors, which are directly linked to the undertaking's business operations, products or services'. ${ }^{116}$ A supplier, then, is 'any undertaking that provides a product, part of a product, or service to another undertaking, either directly or indirectly, in the context of a business relationship', whereas a subcontractor is defined as 'all business relationships that perform a service or an activity that contributes to the completion of

112. Art. L. 225-102-4.-I para. 3 French Commercial Code. See also Savourey, above n. 97, at 61-2.

113. S. Brabant, C. Michon and E. Savourey, 'The Vigilance Plan - Cornerstone of the Law on the Corporate Duty of Vigilance', Revue Internationale de la Compliance et de l'éthique des affaires - Supplément à la semaine juridique entreprise et affaires No. 50 du Jeudi 14 Décembre 2017, at media.business-humanrights.org/media/documents/ba571b 7294311e42b3605af7cc4eeaad149c33b2.pdf, p. 2.

114. Ibid., pp. 2-4

115. Art. 4 EP outline.

116. Art. 3(2) EP outline. 
an undertaking's operations'. ${ }^{117}$ At the same time, the ambit of the EP outline goes beyond both the CLDD Act and the Duty of Vigilance Law as a result of its definition of value chain as:

all activities, operations, business relationships and investment chains of an undertaking [including] entities with which the undertaking has a direct or indirect business relationship, upstream and downstream, and which either: (a) supply products, parts of products or services that contribute to the undertaking's own products or services, or (b) receive products or services from the undertaking. ${ }^{118}$

Particularly interesting in this respect are the definition's reference to 'investment chains' and the fact that it includes not only the upstream but also the downstream portion of the value chain.

\subsubsection{Enforcement}

As discussed in para. 2.1, the enforcement of the CLDD Act will be in the hands of a public law supervisor, which is yet to be appointed. The Act's provisions relating to this supervisor suggest that the supervisor's enforcement actions will need to be initiated by a complaint by a natural or legal person whose interests have been affected by non-compliance by a specific company. Such a complaint can only be filed in relation to specific indications of non-compliance with the Act's provisions by a specific company and will only be dealt with by the supervisor if the same complaint has not been dealt with by the company itself in a timely or satisfactory manner. In response, the supervisor can issue binding orders to non-compliant companies followed by administrative fines. In case of recidivism, criminal sanctions can be imposed on (officers of) the company involved. public or private body in charge of monitoring compliance with its provisions. ${ }^{119}$ Instead, it opens up the possibility for any party with standing to file for an injunction in the competent court in case of non-compliance by one of the companies that fall within its personal scope. Accordingly, the relevant parties can ask the court to order a non-compliant company to comply with one or more provisions of the Law and can also request periodic penalty payments until the defendant does comply with the obligation in question. Before doing so, however, they need to give the company three months' official notice before filing their claim in order to give it a chance to clean up its act. ${ }^{120}$

Comparable to the CLDD Act, supervision of compliance with the requirements set out in the EP outline (which would be transposed to the national law of each member state) is to be exercised by 'one or more nation-

117. Art. 3(3) and 3(4) EP outline, respectively.

118. Art. 3(6) EP outline.

119. Savourey, above n. 97, at 71. and S. Brabant, 'The French Law on the Duty of Vigilance: Theoretical and Practical Challenges Since Its Adoption', 6 Business and Human Rights Journal 141, at 149-51 (2021); Savourey, above n. 97, at 71-3.
The Duty of Vigilance Law does not provide for a

120. Art. L. 225-102-4.-II French Commercial Code. See also E. Savourey

al competent authorities' in each member state. ${ }^{121}$ According to the EP outline, such authorities should have the power necessary to carry out investigations into whether companies that fall within the personal scope of the EP outline comply with the obligations set out in it, including through checks on the companies involved and interviews with (potentially) affected stakeholders. $^{122}$ They can do so autonomously but also in response to substantiated and reasonable concerns of a breach raised by any third party. ${ }^{123}$ If a failure to comply with the requirements set out in the EP outline is identified, the company concerned will be given an appropriate period of time to take remedial action; if it does not or cannot take such action, the competent authorities may impose sanctions, including, in particular, administrative fines. ${ }^{124}$

\subsubsection{Remedies}

As discussed in para. 2.2, the CLDD Act does not contain any provisions relating to access to remedy for the victims of child labour. By consequence, it does not add any new avenues for recourse to those that already exist on the basis of, for example, Dutch tort law (see para. 3). The result is a law that is focused exclusively on rendering certain key components of the responsibility to respect as featured in the UNGPs' second pillar and incorporated in the OECD Guidelines for Multinational Enterprises.

The Duty of Vigilance Law is different in this respect in that it also includes, next to its enforcement mechanism, a provision that allows those suffering damage as a result of non-compliance with the Law to file a civil liability action. ${ }^{125}$ In order to obtain compensation for the harm suffered, the victim will have to prove damage, a breach of one of the obligations set out in the Law, and a causal link between the damage and that breach, in accordance with the general requirements for civil liability in French law as set out in Articles 1240 and 1241 of the French civil code. ${ }^{126}$ However, in the absence of a specific provision to this effect, it remains questionable whether the Law would apply in civil liability cases where the damage has occurred outside of France.

The outline proposed by the EP for a future due diligence directive does mention civil liability but principally defers to the national laws of the member states in this respect. ${ }^{127}$ It does call on the member states to ensure that their national laws allow corporate actors to be held civilly liable for harm arising out of adverse impacts on the matters within the directive's material scope that they, or undertakings under their control, have caused or contributed to. ${ }^{128}$ According to the EP outline, a company shall not be absolved of any liability pursuant to national law by the fact that it respects its

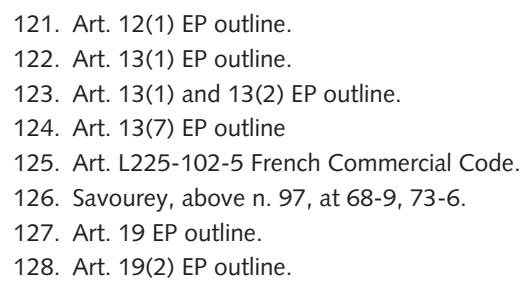


due diligence obligations. At the same time, however, it also stipulates that member states should make sure that companies that took all due care in line with the requirements set out in the EP outline to avoid the harm in question cannot be held liable for that harm under their national laws; the same applies if the harm would have occurred even if all due care had been taken. ${ }^{129}$ Crucially, the EP outline stipulates that member states are to ensure that the directive's provisions as converted into national law are considered as overriding mandatory provisions, meaning that they will apply regardless of the law that is applied in civil liability procedures before EU member state courts relating to IRBC violations by EU-based companies. ${ }^{130}$

\subsection{Discussion}

The comparison between the CLDD Act and the French Duty of Vigilance Law reveals significant differences between many of the key features of these two instruments. The European parliament's outline for a future EU directive on corporate due diligence and corporate accountability seems to be inspired by both existing (if in the case of the CLDD Act so far only on paper) instruments as a number of its key provisions feature a combined approach.

As regards personal scope, the French law is limited to certain large French parent and instructing companies, a group that is estimated to include at least 260 companies from a wide range of sectors. The CLDD Act, by contrast, pertains to companies of all sizes registered both in the Netherlands and abroad. However, it is limited to companies that supply goods or services to Dutch end users and then only to activities relating to those goods and services. Consequently, it does not cover companies that do not supply goods or services at all or companies that do supply them but not to end users or not to Dutch end users, nor does it cover activities related to goods or services that are not intended for Dutch end users. In addition, there is the possibility that certain categories of companies, like SMEs or companies from low-risk sectors, may yet be exempted from the Act's personal scope through secondary legislation.

Owing to their completely different set-up, it is difficult to compare the two instruments with respect to the breadth of their personal scope. Moreover, the actual reach of the CLDD Act can be established only once it becomes operational as was also the case with the French Law (with respect to which there is actually still a measure of uncertainty as regards the number of companies it covers). What can be said, however, is that the personal scope of the future EU directive as envisioned in the recent EP outline is broader than either of the other two instruments as it combines both approaches. By consequence, it covers not only all large European companies, all publicly listed European SMEs and all European SMEs operating in high-risk sectors, but also

129. Art. 19(1) and 19(3) EP outline, respectively 130. Art. 20 EP outline.
non-European companies that sell goods or provide services in the EU internal market.

As regards material scope, the difference between the CLDD Act and the French Duty of Vigilance Law is obvious in that the former focuses on a single issue, child labour, whereas the latter relates to a broad range of issues pertaining to human rights and fundamental freedoms, health and safety of persons, and the environment. The material scope of the French law is broadened further by the fact that these concepts are not defined in the law and/or by reference to other existing frameworks. At the same time, it is limited by a focus on 'risks' and 'severe impacts', a delimitation that does not exist in the CLDD Act. However, depending on how this works out in practice, a limitation may be inherent in the Act's requirement that companies take action (only) if 'a reasonable presumption' of child labour exists after an investigation based on sources that 'can reasonably be known' to the company and that 'are accessible' to it. Regardless, it is clear that the material scope of the French Law is much broader than that of the CLDD Act. The EP outline for a future EU due diligence directive goes even one step further than the French law as regards material scope by also including good governance.

As regards main obligations, a comparison between the CLDD Act's due diligence obligation and the obligation under the French Duty of Vigilance Law to annually draw up a vigilance plan remains impossible as long as further requirements with respect to the scope and content of the investigation and action plan that form the core of the CLDD Act's due diligence obligation remain forthcoming. A marked difference between both instruments is the fact that under the French law companies are required to make public both their vigilance plan and the report on its effective implementation, whereas the CLDD Act merely requires companies to file a declaration that they have conducted due diligence with a view to preventing child labour from having been used in the production of the goods and services they supply to Dutch end users. The Act gives the option of setting further requirements regarding form and contents of such declarations through secondary legislation but does not make this mandatory. It remains to be seen, therefore, whether the Dutch government will give the Act an actual transparency component by requiring the companies involved to make public information relating to their investigation into the possibility that child labour has been used in the production of their goods and services, and to their action plans if such turns out to be the case. If such an obligation would become part and parcel of the CLDD Act's requirements, this would render it comparable to the French law also as regards the transparency aspect.

The approach taken in the EP outline for a future EU due diligence directive is a combination of those in the other two instruments. The main obligation in the EP outline resembles the CLDD Act's two-step approach: investigation of negative impacts followed by establishment and effective implementation of due diligence 
strategy if necessary. It determines that for SMEs and large undertakings with only EU-based direct business relationships a mere statement suffices if the investigation reveals no negative impacts. With respect to other large undertakings, however, the EP outline takes an approach resembling that of the French Duty of Vigilance Law, as they are required to draw up a due diligence strategy no matter what. Similarly, the directive goes beyond the CLDD Act as regards the transparency obligation in requiring that all relevant documents be made publicly available.

The ambit of CLDD Act's due diligence obligation is broader than that of the French Duty of Vigilance Law. It extends, in principle, to all business operations within the value chain, whereas the activities that according to the French law are to be covered by the vigilance plan are those of a circumscribed group of business actors within the value chain. In effect, however, the difference between the two instruments with respect to this particular aspect may be smaller than it seems. Limitations to the ambit of the CLDD Act may not only be inherent in the stipulation that companies within its personal scope only need to look at sources that can reasonably be known to them and are accessible to them for their impact assessments, but may also yet flow from the secondary legislation that will set further requirements with respect to the Act's due diligence obligation. It has, however, been noted that many of the concepts that determine the ambit of the French law lack a clear definition and that the range of actors whose activities are to be covered by the vigilance plan may therefore be very broad in practice.

Likewise, the range of business operations in the value chain that are covered by the due diligence obligation set out in the EP outline for a future EU due diligence directive is very broad. Furthermore, even though it is not unlimited as that of the CLDD Act, the EP outline's ambit goes beyond that of the CLDD Act to the extent that it also includes a company's investment chains and the downstream portion of the value chain (i.e. not only its suppliers but also its buyers).

As regards enforcement, the main difference between the CLDD Act and the French Duty of Vigilance Law is that the CLDD Act places this task in the hands of a public law supervisor, whereas the French law leaves it to the 'competent courts'. In both mechanisms, enforcement is reactive, in the sense that it needs to be initiated by a complaint of non-compliance against a company issued by an interested party or, in the case of the French law, a party with standing to file for an injunction. The sanction for non-compliance by a company even after it has been ordered by the relevant enforcement body to comply is also comparable, except that it consists of a one-time administrative fine in the case of the CLDD Act and a periodic penalty payment as long as the company remains non-compliant in the case of the French Law. Furthermore, the CLDD Act offers a possibility to impose criminal sanctions on companies that are repeat offenders that has no equivalent in the French law. Whether this latter provision will indeed make a real difference in regard to enforcement possibilities remains to be seen, however, as the Dutch public prosecutor's role in enforcing the Act is expected to be limited in practice (see para. 2.2). The proposed enforcement mechanism in the EP outline for a future EU due diligence directive is comparable to that of the CLDD Act. There is a notable difference, however, between the EP outline and both the other instruments in that according to the EP outline, the supervisory authority shall also have the power to carry out independent investigations to determine (non-)compliance.

A distinct difference between the CLDD Act and the French Duty of Vigilance Law is that the latter includes a provision relating to access to remedies for those suffering harm as a result of non-compliance, whereas the former does not. It has to be noted, however, that this difference may be more significant in principle than in practice as the French law's provision on civil liability arguably does not do more than refer to the general provisions on civil liability in the French civil code. The French law does not create a form of risk liability by rendering the parent or instructing company liable for faults committed by other companies in their value chain, nor does it provide for a shift of the burden of proof from the plaintiff to the defendant. Consequently, the plaintiff will still have to prove damage, a breach of one of the obligations set out in the law (fault) and a causal link between the damage and that breach, as in any action based on the French civil code's general provisions on tort liability. Moreover, it should also be noted that in the absence of a specific provision to this effect in the French law, it remains questionable whether it would apply in civil liability cases where the damage has occurred outside of France.

Like the French law, the EP outline for a future EU due diligence directive does include a provision on civil liability. Its (lack of) effect is more or less the same, since the EP outline principally defers to the national laws of the member states in this respect. Accordingly, it does also not in itself improve access to remedies for those suffering harm as a result of non-compliance by the companies covered. In that sense and despite appearances, the three instruments are actually rather comparable in practice as regards their access to remedies aspect. It should be noted that the EP outline does go one step further than the French law by requiring member states to ensure that the directive's provisions are considered overriding mandatory rules and will thus be applied regardless of the applicable law in relevant civil liability procedures.

All in all, the CLDD Act goes beyond the French Duty of Vigilance Law on many counts, including its potentially broad personal scope (which may, however, in effect turn out to be more narrow than it appears), its broad ambit as regards business operations in its value chain covered by the due diligence obligation, and the fact that it will be enforced by a specially designated public law supervisor. At the same time, it is more limited on a number of other counts, including its singleissue material scope focused on child labour, the absence 
of a transparency obligation connected to its due diligence obligation (unless secondary legislation were to be drafted to this effect), and the absence of provisions relating to access to remedy for the victims of child labour (although in practice there will likely not be much of a difference). Whether and in what way these differences will have consequences for the impact of these two similar but different legislative instruments on responsible business conduct not only by the companies covered but also in their value chains, as well as for the impact that these instruments may have 'on the ground', can be established only if and when the CLDD Act comes into effect.

However, the realisation of the CLDD Act has been made contingent by the Dutch government on whether a broad due diligence obligation will be realised at the EU level; if such an instrument were to be adopted, the Dutch government will not bring the CLDD Act into effect. The most recent development in this respect has been the adoption, in March 2021, by the European parliament of a resolution outlining a future EU directive on corporate due diligence and corporate accountability. As is clear from the comparison in para. 4.2, the outline proposed by the EP for a future due diligence directive is ambitious and incorporates many of the key features of the CLDD Act and/or the French Duty of Vigilance Law. It includes virtually all of the aspects that make the CLDD Act stand out in comparison with the French Duty of Vigilance Law and in various respects even goes beyond both mechanisms.

Accordingly, if the EP outline for a future EU due diligence directive were to be adopted in its current form, it would indeed obviate the need to bring the CLDD Act into effect. Whether this will happen is by no means certain, however, as it really remains to be seen how far the European Commission is willing and able to go in adopting an EU-wide due diligence obligation, especially considering that although the number of member states featuring or considering similar mechanisms is growing, those that do still represent a minority. By consequence, the odds are that even if an EU-wide due diligence obligation were to be adopted, uncertainty remains as to the time frame within which this will happen and what the level of ambition of the eventual mechanism will be. This also means that the CLDD Act, uncertain as its future may be, will remain relevant from an international perspective too for some time to come.

\section{Conclusion}

In May 2019, the Dutch senate adopted a private member's bill introducing a due diligence obligation for companies bringing goods or services onto the Dutch market with respect to the use of child labour in their supply chains. In view of subsequent legal and policy developments both in the Netherlands and in the EU, the question may be raised as to the extent to which this CLDD
Act has remained relevant both nationally and internationally. It is argued that the relevance of the Act from a national perspective lies in its introduction of a due diligence obligation relating to IRBC in global value chains that is new to Dutch law, despite the potential of some existing provisions in the fields of Dutch company law and Dutch tort law to give rise to duties of care in this context. A particularly interesting aspect of the law is the public law supervisor that is to be tasked with its enforcement. From an international perspective, the CLDD Act is also novel in the sense that it is the second of its kind worldwide and that it features a number of aspects that make it stand out in comparison with the French Duty of Vigilance Law, which was adopted in 2017. Despite the recent adoption by the European parliament of an ambitious outline for a future EU due diligence directive containing similar obligations in relation to IRBC in global value chains, the CLDD Act also remains relevant internationally so long as it remains uncertain whether this ambition will also be reflected in the actual mechanism, if and when it is realised. 